\title{
Growth and gas exchange of West Indian cherry irrigated with saline waters under combinations of nitrogen-potassium fertilization
}

\author{
Evandro Manoel da Silva ${ }^{1} \oplus$, Reginaldo Gomes Nobre ${ }^{2} \oplus$, Hans Raj Gheyi ${ }^{3} \oplus$, Geovani Soares de Lima ${ }^{1} \oplus$, \\ Joicy Lima Barbosa ${ }^{1}$, Thiago Alves Pimenta ${ }^{4} \oplus$, Reynaldo Teodoro de Fátima ${ }^{5} \odot$, Jutahy Jorge Elias ${ }^{6} \odot$

\footnotetext{
1 Universidade Federal de Campina Grande, Campina Grande-PB, Brasil. E-mail: evandroagroman@hotmail.com; geovanisoareslima@gmail.com; joicy.barbosa0@gmail.com

2 Universidade Federal Rural do Semi-Árido, Caraúbas-RN, Brasil. E-mail: rgomesnobre@pq.cnpq.br

${ }^{3}$ Universidade Federal do Recôncavo Baiano, Cruz das Almas-BA, Brail. E-mail: hans@pq.cnpq.br

${ }^{4}$ Universidade Federal de Alagoas, Rio Largo-AL, Brasil. E-mail: tpimenta62@gmail.com

${ }^{5}$ Universidade Federal da Paraiba, Areia-PB, Brasil. E-mail: reynaldo.t16@gmail.com

${ }^{6}$ Universidade Estadual da Paraíba, Campina Grande-PB, Brasil. E-mail: jutahy.jorge33@gmail.com
}

ABSTRACT: Fertilization management has been one of the techniques used to mitigate salt stress in crops. In this context, this research aimed to study the effect of different combinations of nitrogen and potassium fertilization on growth and gas exchange of the West Indian cherry crop irrigated with salinized water at different vegetative stages. The experiment was conducted in field, in a randomized block design, with treatments arranged in a $5 \times 4$ factorial scheme, referring to five irrigation water salinities (ECw): $0.3,1.3,2.3,3.3$ and $4.3 \mathrm{dS} \mathrm{m}^{-1}$ and four combinations of nitrogen and potassium doses: $\mathrm{C} 1=70 \%+50 \% ; \mathrm{C} 2=100 \%+75 \%$; C3 $=130 \%+100 \%$ and $C 4=160 \%+125 \%$ of $\mathrm{N}$ and $\mathrm{K}_{2} \mathrm{O}$, respectively, of the recommended dose for West Indian cherry, with three replicates and one plant per plot, consisting of a $60 \mathrm{~L}$ pot. Harmful effects of water salinity manifested at 230 days after transplantation (DAT) on the stem and primary shoot diameter, from ECW of $2.32 \mathrm{dS} \mathrm{m}^{-1}$ on, and the tested fertilizer combinations did not mitigate them. Fertilization with $70 \% \mathrm{~N}+50 \% \mathrm{~K}_{2} \mathrm{O}$ favored gas exchange activity and higher plant growth from 170 DAT, regardless of water salinity.

Key words: fertilization management; Malpighia emarginata D. C.; salt stress

\section{Crescimento e trocas gasosas de aceroleira irrigada com águas salinas sob combinações de adubação nitrogenada-potássica}

RESUMO: O manejo da adubação tem sido uma das técnicas utilizadas para mitigação do estresse salino sobre as culturas. Neste sentido, objetivou-se com a pesquisa, estudar a influência de diferentes combinações de adubação nitrogenada e potássica sobre o crescimento e as trocas gasosas da cultura da aceroleira irrigada com água salinizadas, em diferentes épocas na fase vegetativa. $\mathrm{O}$ experimento foi desenvolvido em campo, em delineamento de blocos ao acaso, com os tratamentos dispostos em esquema fatorial $5 \times 4$, referentes a cinco salinidades da água de irrigação (CEa): 0,3; 1,3;2,3;3,3 e 4,3 dS m ${ }^{-1}$ e quatro combinações de adubação nitrogenada-potássica: C1 $=70 \%+50 \%$; C2 $=100 \%+75 \%$; C3 $=130 \%+100 \%$ e C4 $=160 \%$ $+125 \%$ de $\mathrm{N} \mathrm{e} \mathrm{K}_{2} \mathrm{O}$, respectivamente, da dose recomendada para aceroleira, com três repetições e uma planta por parcela constituída de um recipiente de $60 \mathrm{~L}$. Os efeitos nocivos da salinidade da água se manifestaram aos 230 dias após o transplantio (DAT) sobre os diâmetros de caule e de ramos primários, a partir da CEa de 2,32 $\mathrm{dS} \mathrm{m}^{-1}$, sendo que estes efeitos não foram mitigados pelas combinações de adubação testadas. A adubação com $70 \%$ de $\mathrm{N}+50 \%$ de $\mathrm{K}_{2} \mathrm{O}$ favoreceu a atividade das trocas gasosas e maior crescimento das plantas a partir dos 170 DAT, independentemente da salinidade da água.

Palavras-chave: manejo da adubação; Malpighia emarginata D. C.; estresse salino 


\section{Introduction}

West Indian cherry (Malpighia emarginata D. C.) is among the fruit trees of greatest economic interest in Northeastern Brazil, where its exploitation has proved to be an attractive activity due to its adaptation to soil and climate conditions and high content of vitamin $\mathrm{C}$ and anthocyanins, valuing the product on market and increasing its consumption (Calgaro \& Braga, 2012; Souza et al., 2017).

Increasing demand of the product in domestic and foreign markets has been stimulating the formation of new plantings, with conditions for sustainable economic growth (Calgaro \& Braga, 2012). However, in the semi-arid region of Northeastern Brazil, where the production system depends on irrigation, water quality can become a limiting factor, since about $53.20 \%$ of the sources (reservoirs, dams and wells) have salinity above $3.0 \mathrm{dS} \mathrm{m} \mathrm{m}^{-1}$, with severe irrigation restriction (Morais et al., 1998).

Salt excess in irrigation water can compromise the soil physical-chemical properties and the growth, physiology and yield of crops, as in the West Indian cherry case (Alvarenga et al., 2019; Sá et al., 2019; Silva et al., 2019). It reduces the water availability to plants due to the soil solution osmotic effect, causing a toxic effect mainly due the $\mathrm{Na}^{+}$and $\mathrm{Cl}^{-}$ions (Roy et al., 2014; Gupta \& Huang, 2014). It also promotes nutritional imbalance, causing deficiencies of $\mathrm{Ca}^{2+}, \mathrm{Mg}^{2+}, \mathrm{K}^{+}$and $\mathrm{NO}_{3}$, induced by ionic competition with $\mathrm{Na}^{+}$and $\mathrm{Cl}^{-}$accumulated in excess in the soil and plants (Machado \& Serralheiro, 2017).

Therefore, fertilization management strategies must be investigated in order to compensate induced nutritional deficiencies by interaction of toxic ions with nutrients and their accumulation in plants. Sá et al. (2019), studying the effect of nitrogen and phosphorus doses proportions on BRS Jaburu West Indian cherry under irrigation water salinity, observed that increases of $40 \%$ of $N$ and $P$ in relation to the recommended dose mitigate the salt stress effects up to ECW $3.0 \mathrm{dS} \mathrm{m}^{-1}$ in growth, physiology and production, during the first crop cycle. Likewise, Silva et al. (2019) found that combining fertilization with $70 \% \mathrm{~N}+50 \% \mathrm{~K}_{2} \mathrm{O}$ of the recommended dose by Cavalcanti (2008) minimized the negative effects of irrigation water salinity on the fruit diameter of West Indian

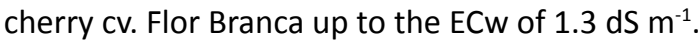

Nitrogen plays a structural role and is part of several vital organic compounds to the plant, such as low molecular weight compounds (amino acids, glycinabetaine, proline, oligosaccharides, etc.), which act in the osmotic adjustment of plants under salinity conditions (Zaki, 2016; Arghavani et al., 2017). On the other hand, potassium promotes the control of cell turgidity, activation of enzymes involved in respiration and photosynthesis, regulation of the opening and closing stomata processes, transpiration and transport of carbohydrates, which are fundamental factors involved in controlling osmotic adjustment of plants to the salinity (Wang et al., 2013).

Therefore, it is worth noting the importance of analyzing the effect of combining doses of these nutrients on acerola plants irrigated with saline waters. The study is still important when analyzed at different growth times, considering that this can become a basic tool in determining the best management of fertilization and irrigation for forming West Indian cherry orchards, which may reflect in the future in expressing the maximum productive potential of the crop.

In this sense, the objective of the research was to study the influence of different combinations of nitrogen and potassium fertilization on the growth and gas exchange of the West Indian cherry crop irrigated with salinized water, at different vegetative stages.

\section{Materials and Methods}

The research was conducted under field conditions, with the plants grown in $60 \mathrm{~L}$ containers, between April 19 and December 5, 2017, in an experimental area belonging to the Center of Science and Agrifood Technology (CCTA) of the Federal University of Campina Grande (UFCG), Pombal, PB. Local reference geographical coordinates $6^{\circ} 48^{\prime} 16^{\prime \prime}$ South, $37^{\circ} 49^{\prime} 15^{\prime \prime}$ West and mean altitude is of $144 \mathrm{~m}$. Precipitation data were from a conventional pluviometer set up at the experiment site and, temperature and relative humidity (Figure 1) were acquired at the automatic weather station from São Gonçalo (Sousa - PB), property of INMET (2018).

A randomized block design was used, with treatments arranged in a $5 \times 4$ factorial scheme, referring to five levels of irrigation water salinity: electrical water conductivity (ECW) of $0.3 ; 1.3 ; 2.3 ; 3.3$ and $4.3 \mathrm{dS} \mathrm{m} \mathrm{m}^{-1}$ and four combinations (C) of nitrogen $(\mathrm{N})$ and potassium $\left(\mathrm{K}_{2} \mathrm{O}\right)$ doses: $\mathrm{C} 1=70 \%+$ $50 \%$; C2 $=100 \%+75 \%$; C3 $=130 \%+100 \%$ and C4 $=160 \%+$ $125 \%$ of $\mathrm{N}$ and $\mathrm{K}_{2} \mathrm{O}$, respectively, of the recommended dose for West Indian cherry. Three replicates were used, with the experimental plot consisting of a $60 \mathrm{~L}$ container with a plant, totaling 60 containers in all the experiment.

Saline levels were based on the study by Sá et al. (2019), who found that irrigation with saline water up to $2.2 \mathrm{dS} \mathrm{m}^{-1}$ and application of $10 \%$ leaching fraction did not compromise

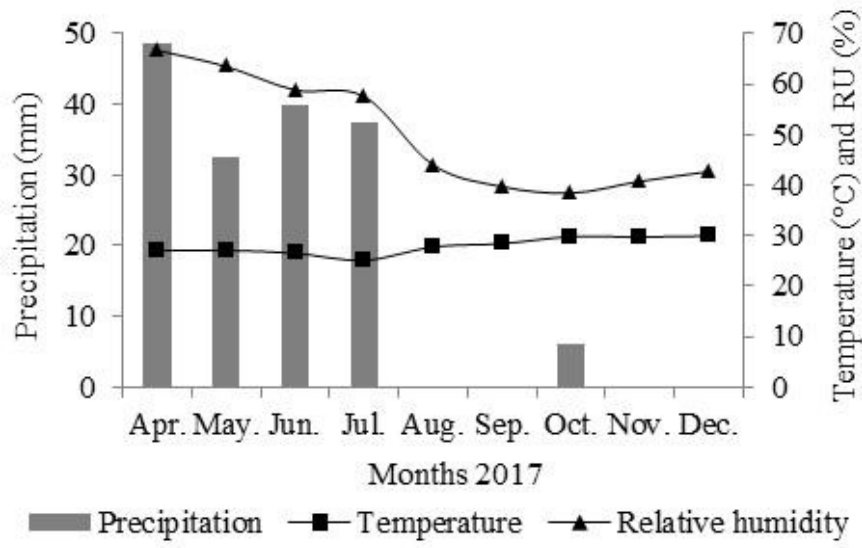

Figure 1. Mean data from precipitation, average temperature and relative humidity - $R U$, in the study period between April 19 and December 5, 2017. 
the growth, photosynthetic activity and production of the acerola cv. BRS 336-Jaburu in the first cultivation year, grown in a medium-textured soil.

The saline waters used in treatments from 1.3 to $4.3 \mathrm{dS}$ $\mathrm{m}^{-1}$ were obtained by the addition of $\mathrm{NaCl}, \mathrm{CaCl}_{2} \cdot 2 \mathrm{H}_{2} \mathrm{O}$ and $\mathrm{MgCl}_{2} \cdot 6 \mathrm{H}_{2} \mathrm{O}$ in the $7: 2: 1$ equivalent ratio, respectively, to the

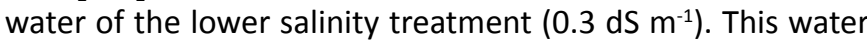
was from the Coremas-Mãe d’Água reservoir system, which provides irrigation water for crops in the region. This salt proportion is predominantly found in the main water sources for irrigation in Northeastern Brazil, obeying the relation between ECw $\left(\mathrm{dS} \mathrm{m}^{-1}\right)$ and the salt concentration $\left(\mathrm{mmol}_{\mathrm{c}} \mathrm{L}^{-1}=\right.$ ECw x 10) (Medeiros, 1992).

The used fertilization was according to the recommendation for West Indian cherry cv. Flor Branca irrigated in the first cultivation year, corresponding to $100 \mathrm{~g}$ of $\mathrm{N}$ and $80 \mathrm{~g}$ of $\mathrm{K}_{2} \mathrm{O}$ per plant (Cavalcanti, 2008), which are equivalent to the $100 \%$ nitrogen and potassium doses used in the treatments. The $\mathrm{K}_{2} \mathrm{O}$ dose was determined according to the availability of $\mathrm{K}$ in the soil (Table 1), as recommended by the aforementioned author.

Doses were planned to be split in 24 applications at an interval of 15 days in the first year (360 days). Hence, until evaluation periods of 110, 170 and 230 DAT, 6, 10 and 14 applications of $\mathrm{N}$ and $\mathrm{K}_{2} \mathrm{O}$, respectively, were held in equal parts at intervals of 15 days, totaling applications of $58.33 \mathrm{~g}$ of $\mathrm{N}$ and $46.67 \mathrm{~g}$ of $\mathrm{K}_{2} \mathrm{O}$ doses up to $230 \mathrm{DAT}$, corresponding to the $100 \%$ doses used in the treatments. Urea $(45 \% \mathrm{~N})$ and potassium chloride $\left(60 \% \mathrm{~K}_{2} \mathrm{O}\right)$ were the sources of $\mathrm{N}$ and $\mathrm{K}_{2} \mathrm{O}$, respectively. Application of $\mathrm{N}$ and $\mathrm{K}$ doses began at $20 \mathrm{DAT}$, made simultaneously in topdressing by the conventional method, in a circle, with a radius of $20 \mathrm{~cm}$ in relation to the plant base.

The $111.11 \mathrm{~g}$ dose of simple superphosphate $\left(18 \% \mathrm{P}_{2} \mathrm{O}_{5}\right)$ was applied for phosphate fertilization, in a single application, by mixing the fertilizer to the soil of each container. The phosphorus applied dose per plant was $20 \mathrm{~g}$ of $\mathrm{P}_{2} \mathrm{O}_{5}$ determined according to the availability of phosphorus in the soil (Table 1), after chemical analysis, obeying the fertilization recommendation for irrigated West Indian cherry cv. Flor Branca in the first cultivation year (Cavalcanti, 2008).

Initially, up to 40 days after transplanting (DAT), irrigation of the plants was done with water having $0.3 \mathrm{dS} \mathrm{m}^{-1}$ of electrical conductivity. Application of saline water began at 41 DAT, when the seedlings were already acclimated to field conditions. From this period on, daily irrigation was manually performed, with water of the respective treatment, based on the principle of drainage lysymmetry. This principle states that the applied volume in each irrigation is determined by the difference between the applied and the drained volume on the next day, where this difference value is equivalent to the water volume needed for the soil to reach its maximum water retention capacity (field capacity).

A leaching fraction of $15 \%$ was adopted every 15 days, with the determination of the leaching volume based on the water volume applied in this period, aiming to reduce the excessive salt accumulation in the root zone of the plants.

The seedlings came from a commercial nursery accredited by the National Registry of Seeds and Seedlings, located in São Gonçalo District (Sousa-PB), grafted by cleft grafting, by using rootstock and graft from Junco and Flor Branca cultivars, respectively, grown in polyethylene bags with dimensions of $10 \times 20 \mathrm{~cm}$ and a $0.5 \mathrm{~L}$ capacity. These cultivars are adapted to edaphoclimatic conditions of the semi-arid region of Northeastern Brazil and are among the main ones planted in Irrigated Perimeters of São Francisco Valley. Characterized by starting production at 6 months after transplanting under irrigation and showing high yield (up to $100 \mathrm{~kg} \mathrm{plant}^{-1}$ year $^{-1}$ ), the fruits have a reddish coat, weight between 3 and $5 \mathrm{~g}$ and

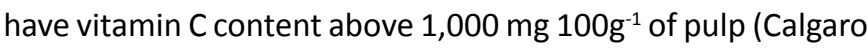
\& Braga, 2012).

Transplantation was performed at 120 days after grafting, when seedlings were 30 to $40 \mathrm{~cm}$ high, into $60 \mathrm{~L}$ plastic containers with dimensions of 0.615 (height), 0.510 (upper diameter) and $0.435 \mathrm{~m}$ (lower diameter), placed at a height of $20 \mathrm{~cm}$ from the ground on ceramic bricks, spaced at $1.8 \mathrm{x}$ $2.0 \mathrm{~m}$ between plants and rows, respectively,. The containers occupied an area of $216 \mathrm{~m}^{2}$ and received a drainage system at their base, consisting of a drain with a diameter of $1 / 2$ " $(12.7 \mathrm{~mm})$ inserted at the base and coupled to a $2 \mathrm{~L}$ PET bottle for collecting drained water. A $3.0 \mathrm{~cm}$ layer of crushed gravel No. 1 and $2.0 \mathrm{~cm}$ of washed sand were also placed at the bottom of the container. Above the sand, $56 \mathrm{~L}$ of Eutrophic Fluvic Neosol (Eutrophic Fluvent Entisol) were placed, whose

Table 1. Physical-chemical attributes of the Eutrophic Fluvic Neosol (Eutrophic Fluvent Entisol) used in the experiment, collected in the 0-20 cm layer from Lot 14, Sector I, from the Irrigated Perimeter of 'Várzeas de Sousa'-PB.

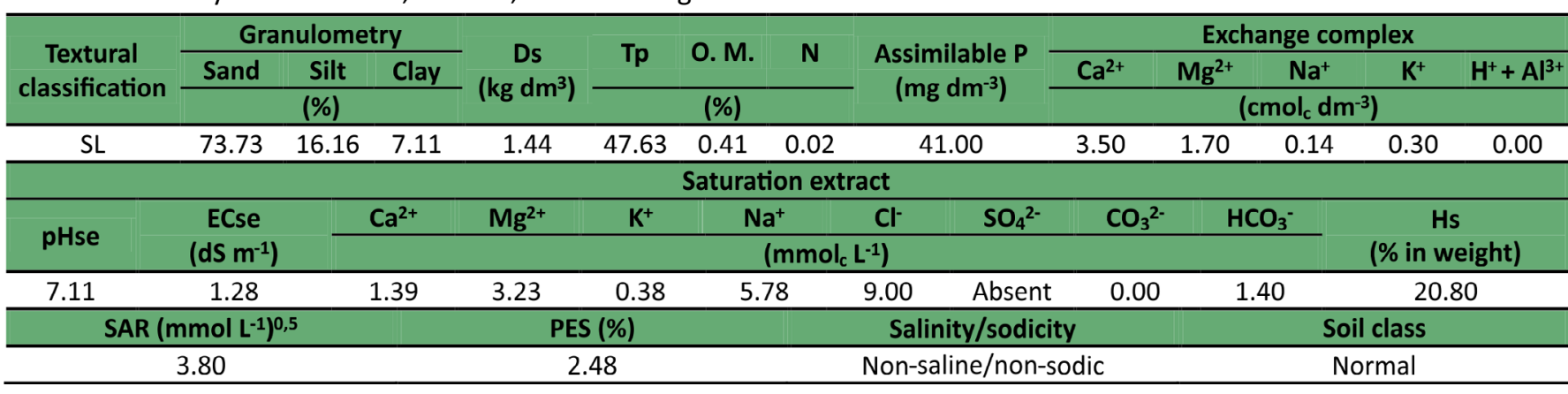

$\mathrm{SL}$ - Sandy loam; Ds - Soil density; Tp - Total porosity; O.M. - Organic matter; pHse - saturation extract pH, ECse - saturation extract electrical conductivity at $25^{\circ} \mathrm{C}$; $\mathrm{Hs}-$ soil saturation humidity (\% based on weight); SAR - Sodium adsorption ratio; ESP - Exchangeable sodium percentage; $\mathrm{P}^{\mathrm{K}^{+}}$and $\mathrm{Na}^{+}$extracted with $\mathrm{Mehlich}-1$ extractor; $\mathrm{Ca}^{2+}$ and $\mathrm{Mg}^{2+}$ extracted with $\mathrm{KCl} 1.0 \mathrm{M} \mathrm{L}^{-1}$ extractor at $\mathrm{pH} 7.0 ; \mathrm{H}^{+}+\mathrm{Al}^{3+}$ extracted by $0.5 \mathrm{M} \mathrm{CaOAc}$ at $\mathrm{pH}$ 7.0; M.O: Walkley-Black wet digestion. 
physical and chemical attributes (Table 1) were determined at the Irrigation and Salinity Laboratory of the Center of Technology and Natural Resources (CTRN) of UFCG.

After transplanting the seedlings, a $4.0 \mathrm{~cm}$ layer of mulch, consisting of grass remains, was also placed in order to minimize water losses through evaporation. Wooden rods that served as tutors were used, with $80 \mathrm{~cm}$ height to support the plants, in order to allow upright growth and avoid damping-off.

Plants were conducted on a single stem and their apical bud was pruned after reaching $50 \mathrm{~cm}$ of height at 70 DAT, thereby stimulating the lateral buds. From the lateral shoots that emerged, three shoots were left at different heights, radially distributed in the $20 \mathrm{~cm}$ terminals of the main stem, also called primary shoots. These shoots were pruned when reached $60 \mathrm{~cm}$ in length at 180 DAT, in order to stimulate the sprouting of secondary shoots and to control the lateral growth, adapting the plants to the spacing in the experimental area. During pruning, the "normal" shoots, suckers (wild shoots), poorly located shoots and those that faced the soil were all eliminated (Calgaro \& Braga, 2012).

Flowering started 5 months after transplanting (150 DAT); however, because the plants are still small and not able to produce, the flowers were manually eliminated up to 230 DAT, so that early production would not compromise the growth of plants and, in the future, the crop productive potential.

For evaluating the West Indian cherry growth, plants were measured at 110; 170 and 230 DAT. In the 110 and 170 DAT periods, the stem diameter below the grafting (DSbe) was analyzed at the grafting point (DSpo), above the grafting (DSab), primary shoot diameter (DSHpr), primary shoot length (LSHpr), number of shoots (NSHpl) and leaves (NL) per plant. At $230 \mathrm{DAT}$, when the pruning of primary shoots had already been done, DSbe, DSpo, DSab, DSHpr and NSHpl were evaluated.

DSbe was measured at $2.0 \mathrm{~cm}$ from the soil surface. DSpo was determined at the connection point between rootstock/ graft and DSab at $4.0 \mathrm{~cm}$ above the grafting point. DSHpr was measured at $2.0 \mathrm{~cm}$ from the point of connection of the shoot with the plant stem. LSHpr was measured from the base of the shoot to the apical bud emission point. Values of DSHpr and LSHpr were obtained by the mean of three primary shoots that each plant had. NSHpl was found by counting shoots which were larger than $4.0 \mathrm{~cm}$ in length on the plant, and the NL was determined by counting, considering those with a fully open leaf blade.

Gas exchanges in plants were evaluated at 170 and 230 DAT, using the variables of transpiration (E), stomatal conductance (gs), $\mathrm{CO}_{2}$ assimilation rate (A) and instant carboxylation efficiency (EiCi), by using the carbon dioxide analyzer the portable infrared (IRGA), model LCPro + Portable Photosynthesis System (ADC BioScientific Limted, UK), operating with temperature set at $25^{\circ} \mathrm{C}$, irradiation of $1200 \mu \mathrm{mol}$ photons $\mathrm{m}^{-2} \mathrm{~s}^{-1}$ and air flow of $200 \mathrm{~mL} \mathrm{~min}^{-1}$, and atmospheric $\mathrm{CO}_{2}$ concentration. Instant efficiency of carboxylation (EiCi) was determined by the ratio between the rate of $\mathrm{CO}_{2}$ assimilation and the intercellular concentration of this gas (Ci) (Melo et al., 2009).
Means of the variables were subjected to analysis of variance by the $F$ test at the level of 0.05 and 0.01 of probability, with the data on the salinity levels analyzed by regression, and the means obtained in the plants in function of the combinations of nitrogen and potassium fertilization treatments compared by Tukey test at 0.05 probability level. All analyses were performed by using the statistical software SISVAR/UFLA for data processing (Ferreira, 2011).

\section{Results and Discussion}

None of the growth variables responded significantly $(p>$ 0.05 ) to the interaction between irrigation water salinity and combinations of nitrogen and potassium fertilization in the periods of 110, 170 and 230 days after transplanting (Table 2). Regarding the water salinity factor, there was an isolated significant effect $(p<0.01)$ on the stem (DSbe, DSpo) and shoots (DSHpr) diameters at 230 DAT. The isolated effect $(p<0.05)$ from the combination of nitrogen and potassium fertilization (NK) was manifested on DSHpr from 110 DAT on; DSbe and DSpo at 170 DAT and over all evaluated diameters in the 230 DAT period, while LSHpr, NSHpl and NL were not affected by the studied factors in the different periods evaluated.

Probably, the accumulated precipitation of $158.5 \mathrm{~mm}$ up to 90 DAT (July 2017) (Figure 1) contributed to leaching excess salts from the soil, reducing the negative effects on plant growth until 110 DAT.

At 170 DAT (October 2017), when plants were exposed for a longer time to salinity (Figure 1), the non-significant effect on growth variables (Table 2) may be associated with the crop acclimatization to salt stress, such as the occurrence of $\mathrm{Na}^{+}$exclusion from cells to the apoplastic space and compartmentalization of toxic ions to the vacuole (Gupta \& Huang, 2014). It can be also attributed to osmotic adjustment by the accumulation of low molecular weight organic solutes in the cytoplasm of plant tissue cells, as reported by Alvarenga et al. (2019) when verifying a non-significant effect of irrigation water salinity on the growth of acerola plants 200 days after transplanting.

In the 230 DAT period, the increase in irrigation water salinity linearly decreased the DSbe, DSpo and DSab of grafting and the DSHpr (Figure 2A; Figure 2B; Figure $2 \mathrm{C}$ and Figure 2D), whose reductions were of $4.76 ; 4.31 ; 4.70$ and $3.45 \%$, respectively, for each unit increase in the electrical conductivity of the irrigation water. Based on the regression equations, a relative reduction of $10 \%$ over the DSbe and DSpo was estimated at the ECW level of $2.1 \mathrm{dS} \mathrm{m}^{-1}$ and DSab and DSHpr in the ECW of 2.3 and $2.8 \mathrm{dS} \mathrm{m}^{-1}$, respectively, equivalent to $E C W$ mean of $2.32 \mathrm{dS} \mathrm{m}^{-1}$.

According to Ayers \& Westcot (1999), a relative reduction of $10 \%$ can be considered as acceptable in plants grown under salinity. Thus, the growth of plants in diameter is inferred as not compromised, when irrigated with water of up to 2.32 $\mathrm{dS} \mathrm{m}^{-1}$, at 230 DAT.

Foremost, the decrease in stem diameters and primary shoots of plants due to the increase in ECW is noteworthy, 
Table 2. Summary of analysis of variance for stem diameter below grafting (DSbe), at the grafting point (DSpo), above grafting (DSab), diameter (DSHpr) and lengths of primary (LSHpr) and secondary shoots (LSHsec), numbers of shoots (NSHpl) and leaves (NL) per plant in West Indian cherry plants irrigated with saline waters, under combinations of nitrogen and potassium (NK) doses at 110, 170 and 230 days after transplanting (DAT).

\begin{tabular}{|c|c|c|c|c|c|c|c|c|}
\hline \multirow{3}{*}{ Variation source } & \multicolumn{8}{|c|}{ Mean square } \\
\hline & \multicolumn{8}{|c|}{110 DAT } \\
\hline & $\mathrm{DF}$ & DSbe & DSpo & DSab & DSHpr & LSHpr & NSHp| ${ }^{1}$ & $\mathrm{NL}^{1}$ \\
\hline Water salinity (S) & 4 & $0.250^{\mathrm{NS}}$ & $0.721^{\mathrm{NS}}$ & $0.229^{\mathrm{NS}}$ & $0.201^{\mathrm{NS}}$ & $46.256^{\mathrm{NS}}$ & $1.333^{\mathrm{NS}}$ & $5.037^{\mathrm{NS}}$ \\
\hline NK combination (C) & 3 & $0.948^{\mathrm{NS}}$ & $1.389^{N S}$ & $0.743^{\mathrm{NS}}$ & $0.692 *$ & $65.141^{\mathrm{NS}}$ & $4.229^{N S}$ & $3.420^{\mathrm{NS}}$ \\
\hline Interaction $\mathrm{S}^{*} \mathrm{C}$ & 12 & $0.386^{\mathrm{NS}}$ & $0.629^{N S}$ & $0.461^{\mathrm{NS}}$ & $0.340^{\mathrm{NS}}$ & $36.987^{\mathrm{NS}}$ & $2.561^{\mathrm{NS}}$ & $4.237^{\mathrm{NS}}$ \\
\hline Block & 2 & $0.912^{\mathrm{NS}}$ & $0.612^{\mathrm{NS}}$ & $1.312^{\mathrm{NS}}$ & $0.683^{\mathrm{NS}}$ & $71.680^{\mathrm{NS}}$ & $4.513^{\mathrm{NS}}$ & $28.273^{* *}$ \\
\hline Residue & 38 & 0.860 & 0.788 & 0.628 & 0.173 & 28.199 & 2.120 & 4.181 \\
\hline \multirow[t]{3}{*}{ CV (\%) } & - & 12.79 & 11.70 & 12.51 & 14.95 & 19.14 & 31.64 & 22.40 \\
\hline & \multicolumn{8}{|c|}{170 DAT } \\
\hline & $\mathrm{DF}$ & DSbe & DSpo & DSab & DSHpr & LSHpr & NSHpl & $\mathbf{N L}$ \\
\hline Water salinity (S) & 4 & $3.318^{\mathrm{NS}}$ & $1.422^{\mathrm{NS}}$ & $1.529^{\mathrm{NS}}$ & $0.650^{\mathrm{NS}}$ & $208.181^{\mathrm{NS}}$ & $334.92^{\mathrm{NS}}$ & $49197.7^{\mathrm{NS}}$ \\
\hline NK combination (C) & 3 & $6.814^{*}$ & $5.016 *$ & $3.046^{\mathrm{NS}}$ & $2.240^{*}$ & $270.800^{\text {NS }}$ & $179.85^{N S}$ & $38461.0^{\mathrm{NS}}$ \\
\hline Interaction $\mathrm{S}^{*} \mathrm{C}$ & 12 & $1.749^{\mathrm{NS}}$ & $1.765^{\mathrm{NS}}$ & $1.146^{\mathrm{NS}}$ & $0.568^{\mathrm{NS}}$ & $204.301^{\text {NS }}$ & $220.97^{\mathrm{NS}}$ & $54575.4^{\mathrm{SN}}$ \\
\hline Block & 2 & $1.586^{\mathrm{NS}}$ & $0.806^{N S}$ & $1.093^{\mathrm{NS}}$ & $1.198^{\mathrm{NS}}$ & $82.582^{\mathrm{NS}}$ & $35.31^{\mathrm{NS}}$ & $118778.1^{\text {NS }}$ \\
\hline Residue & 38 & 1.718 & 1.528 & 1.540 & 0.548 & 152.00 & 180.43 & 34312.1 \\
\hline \multirow[t]{3}{*}{ CV (\%) } & - & 12.66 & 12.78 & 14.50 & 13.60 & 17.46 & 32.80 & 37.01 \\
\hline & \multicolumn{6}{|c|}{230 DAT } & & \\
\hline & DF & DSbe & DSpo & DSab & DSHpr & NSHpl & & \\
\hline Water salinity (S) & 4 & $20.615^{* *}$ & $13.323^{* *}$ & $13.120^{* *}$ & $13.210^{* *}$ & $363.483^{\text {NS }}$ & & \\
\hline NK combination (C) & 3 & $16.674 *$ & $22.021 * *$ & $14.441 * *$ & $4.636^{* *}$ & $17.749^{N S}$ & & \\
\hline Interaction $\mathrm{S}^{*} \mathrm{C}$ & 12 & $4.921^{\mathrm{NS}}$ & $3.555^{\mathrm{NS}}$ & $3.150^{\mathrm{NS}}$ & $1.066^{\mathrm{NS}}$ & $587.450^{\mathrm{NS}}$ & & \\
\hline Block & 2 & $3.114^{\mathrm{NS}}$ & $2.671^{\text {NS }}$ & $2.242^{\mathrm{NS}}$ & $0.809^{\mathrm{NS}}$ & $1364.212^{\mathrm{NS}}$ & & \\
\hline Residue & 38 & 3.941 & 2.668 & 2.642 & 0.814 & $339.458^{\text {NS }}$ & & \\
\hline CV (\%) & - & 13.74 & 12.78 & 13.53 & 11.44 & 23.42 & & \\
\hline
\end{tabular}

$\mathrm{NS},{ }^{* *}$, respectively not significant and significant at $\mathrm{p}<0.01 ;{ }^{1}$ statistical analysis performed after data transformation in $\mathrm{Vx}$; DF $=$ degrees of freedom; CV $=$ coefficient of variation.
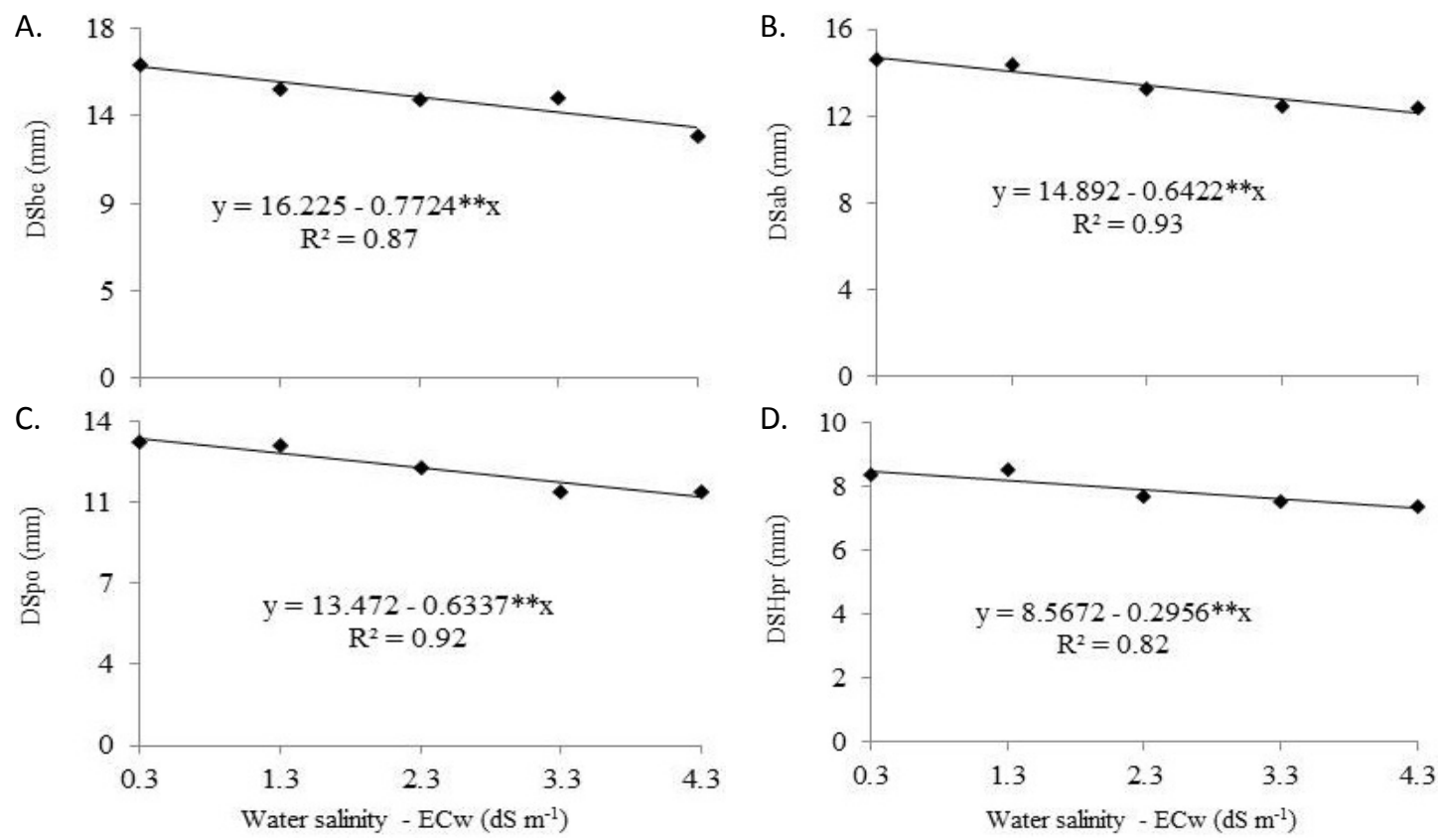

Figure 2. Stem diameter below the grafting - DSbe (A), above the grafting - DSab (B), at the grafting point - DSpo (C) and diameter of primary shoots - DSHpr (D) in West Indian cherry plants as a function of water salinity irrigation - ECW, 230 days after transplanting - DAT. ${ }^{* *}$ significant at $\mathrm{p} \leq 0.01$.

since it may have been due to the longer exposure time to salinity, where toxic ions concentrations may have excessively accumulated in stem tissues at 230 DAT, for not being sufficiently excluded or compartmentalized.
In these conditions, the displacement of $\mathrm{Ca}^{2+}$ from the cell wall binding sites, mainly in the meristematic stem tissues, may have occurred, caused by the $\mathrm{Na}^{+}$excess, reducing the pectin crosslinking and, subsequently, cell elongation and 
division (Li, et al., 2014; Byrt et al., 2018). This may have led to a compromised growth in stem diameter at this evaluated time, mainly above the ECW of $2.32 \mathrm{dS} \mathrm{m}^{-1}$.

Combination of the lowest nitrogen and potassium dosages ( $\mathrm{C} 1=70 \% \mathrm{~N}+50 \% \mathrm{~K}_{2} \mathrm{O}$ ) provided greater growth of the grafting DSbe and DSpo at 170 and 230 DAT (Figure 3A and Figure 3B); DSab from grafting at 230 DAT (Figure 3C) and DSHpr at 110, 170 and 230 DAT (Figure 3D). These doses combination may have provided a greater nutritional balance in the plants, favoring both physiological and biochemical activities, with a positive impact on the stem diameters growth.

Fertilization with combination of C2, C3 and C4 doses decreased the plants growth in diameter at different evaluation times, in relation to the combination $\mathrm{C} 1$ (Figure 3A; Figure 3B; Figure 3C and Figure 3D). Such phenomenon may be associated with some nutritional imbalance caused by higher doses of $\mathrm{N}$ and $\mathrm{K}_{2} \mathrm{O}$, since their excess can induce deficiency or excessive accumulation of others, leading to a nutritional disorder that can affect the plants growth (Taiz et al., 2017). As an example, excessive doses of $\mathrm{K}^{+}$decrease the absorption of $\mathrm{Ca}^{2+}$ and $\mathrm{Mg}^{2+}$ by plants, through the dilution effect or competitive inhibition between these ions (Silva \& Trevizam, 2015). In these conditions, a deficiency of these bivalent cations that are part of the cell wall and chlorophyll molecules composition may happen, negatively affecting plant growth (Taiz et al., 2017).

As for gas exchange, the interaction between water salinity and the combination of nitrogen-potassium fertilization was not significant ( $p>0.05$ ) at 110 and 230 DAT (Table 3). However, there was an isolated significant effect $(p<0.05)$ of irrigation
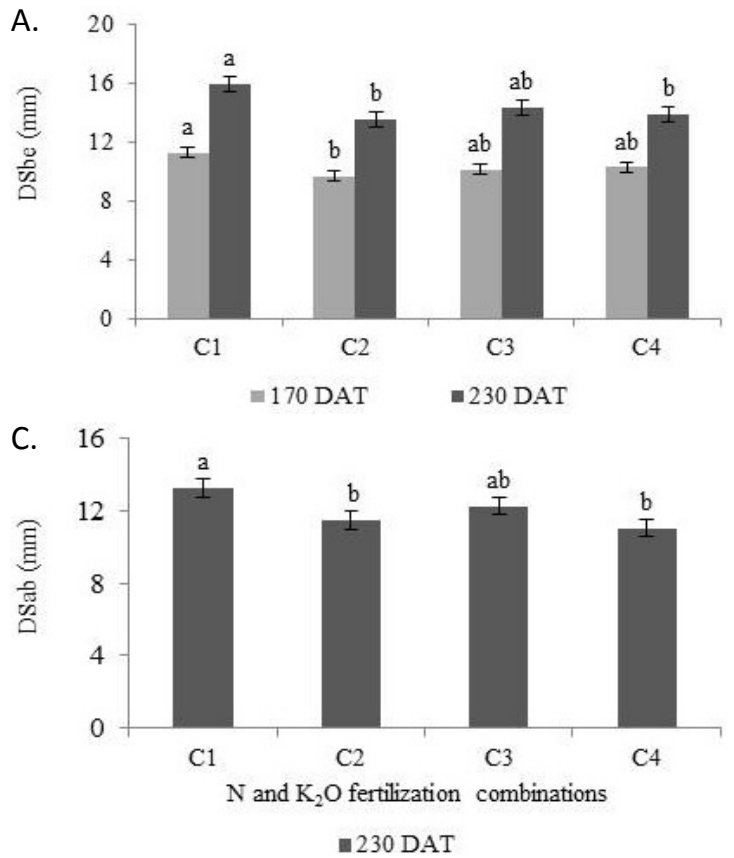

water salinity on stomatal conductance, transpiration and $\mathrm{CO}_{2}$ assimilation rate at $170 \mathrm{DAT}$, and the NK fertilizer combination factor for all variables at 230 DAT.

Increasing salinity in irrigation water linearly decreased stomatal conductance, transpiration and $\mathrm{CO}_{2}$ assimilation rate at 110 DAT (Figure 4A, Figure 4B and Figure 4C), causing reductions of $11.03 ; 10.13$ and $10.07 \%$, respectively, by an unit increase in ECw. Variation in osmotic potential in the root zone, caused by increasing electrical conductivity of irrigation water, may have been the main cause of the gas exchange decrease. Considering that when plants are subjected to these said conditions, a sequence of reactions modulated by hormones is triggered as an acclimative physiological response, which in turn leads to restriction of stomatal opening, with reflex on transpiration and the assimilation rate of $\mathrm{CO}_{2}$ (Silveira et al., 2016).

Lower transpiration caused by salinity increase (Figure 4B) was due the decrease in stomatal opening (Figure 4A), which consequently decreased water losses to the atmosphere in vapor form; and also restricted the $\mathrm{CO}_{2}$ entry into the cells, resulting in a lower rate of $\mathrm{CO}_{2}$ assimilation (Figure $4 \mathrm{C}$ ), as already verified in soursop plants (Silva et al., 2018).

In turn, at 230 DAT, other mechanisms of plants acclimatization to salinity may have predominated, minimizing osmotic and toxic effects on gas exchange. For example, accumulation of low molecular weight organic solutes in the cytoplasm; compartmentalization of toxic ions for cell vacuole and minimizing the translocation of $\mathrm{Na}^{+}$and $\mathrm{Cl}^{-}$ions to the aerial part, specifically to the leaves, thus decreasing their concentrations, are the main causes of stomatal and
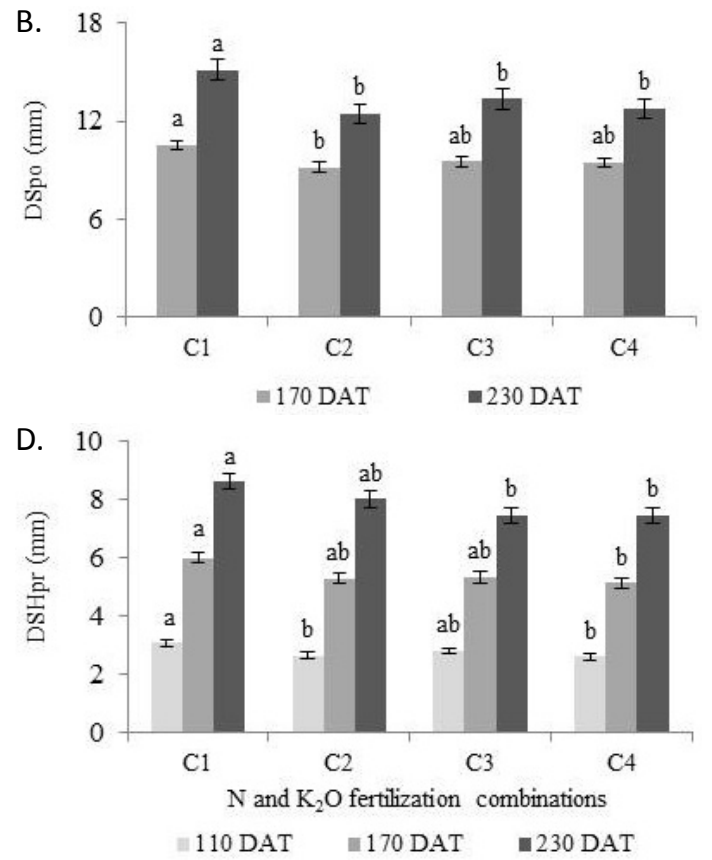

Figure 3 . Stem diameter below the grafting - DSbe (A), at the grafting point - DSpo (B) above the grafting - DSab (C), and primary shoot diameter - DSHpr (D) in West Indian cherry plants fertilized with different nitrogen $(\mathrm{N})$ and potassium $\left(\mathrm{K}_{2} \mathrm{O}\right)$ dose combinations, at 110, 170 and 230 days after transplanting - DAT. Means followed by different letters indicate a significant difference between treatments within each time after transplantation using the Tukey test $(p<0.05)$. Bars represent the standard error of the mean $(n=3)$. 
Table 3. Summary of analysis of variance for stomatal conductance (gs), transpiration (E), $\mathrm{CO}_{2}$ assimilation rate (A) and instant carboxylation efficiency $(\mathrm{EiCi})$ in West Indian cherry plants irrigated with saline water, under different combinations of nitrogen and potassium fertilization, at 110 and 230 days after transplantation - DAT.

\begin{tabular}{|c|c|c|c|c|c|}
\hline \multirow{3}{*}{ Variation Source } & \multicolumn{5}{|c|}{ Mean Square } \\
\hline & \multicolumn{5}{|c|}{110 DAT } \\
\hline & DF & $\mathbf{g s}^{1}$ & $E^{1}$ & $A^{1}$ & $\mathrm{EiCi}^{1}$ \\
\hline Water salinity (S) & 4 & $0.008002^{* *}$ & $0.114299 *$ & $0.936936 * *$ & $0.005374^{\mathrm{NS}}$ \\
\hline NK Fertilizations (NK) & 3 & $0.001292^{\mathrm{NS}}$ & $0.022964^{\mathrm{NS}}$ & $0.097891^{\mathrm{NS}}$ & $0.002779^{\mathrm{NS}}$ \\
\hline Interaction S*NK & 12 & $0.001624^{\mathrm{NS}}$ & $0.024720^{\mathrm{NS}}$ & $0.084529^{\mathrm{NS}}$ & $0.003962^{\mathrm{NS}}$ \\
\hline Block & 2 & $0.003243^{\mathrm{NS}}$ & $0.129141 *$ & $0.246762^{\mathrm{NS}}$ & $0.001100^{\mathrm{NS}}$ \\
\hline Residue & 38 & 0.001723 & 0.030248 & 0.136606 & 0.002498 \\
\hline \multirow[t]{3}{*}{ CV (\%) } & 4 & 20.96 & 20.34 & 16.10 & 24.95 \\
\hline & \multicolumn{5}{|c|}{230 DAT } \\
\hline & DF & gs & $E$ & A & EiCi \\
\hline Water salinity (S) & 4 & $0.000073^{\mathrm{NS}}$ & $0.040207^{\mathrm{NS}}$ & $1.824723^{\mathrm{NS}}$ & $0.000241^{\mathrm{NS}}$ \\
\hline NK Fertilizations (NK) & 3 & $0.000539 *$ & $0.219771^{*}$ & $8.085046 * *$ & $0.000509 * *$ \\
\hline Interaction S*NK & 12 & $0.000216^{\mathrm{NS}}$ & $0.071660^{\mathrm{NS}}$ & $2.424849^{\mathrm{NS}}$ & $0.000184^{\mathrm{NS}}$ \\
\hline Block & 2 & $0.001340^{* *}$ & $0.308887^{* *}$ & $14.596552^{* *}$ & $0.000328^{*}$ \\
\hline Residue & 38 & 0.000126 & 0.039157 & 1.50795 & 0.000092 \\
\hline CV (\%) & 4 & 24.14 & 19.28 & 21.50 & 26.16 \\
\hline
\end{tabular}

$\mathrm{NS},{ }^{* *}$, respectively not significant and significant at $\mathrm{p}<0.01 ;{ }^{1}$ statistical analysis performed after data transformation in $\mathrm{Vx} ; \mathrm{DF}=$ degrees of freedom; $\mathrm{CV}=$ coefficient of variation.
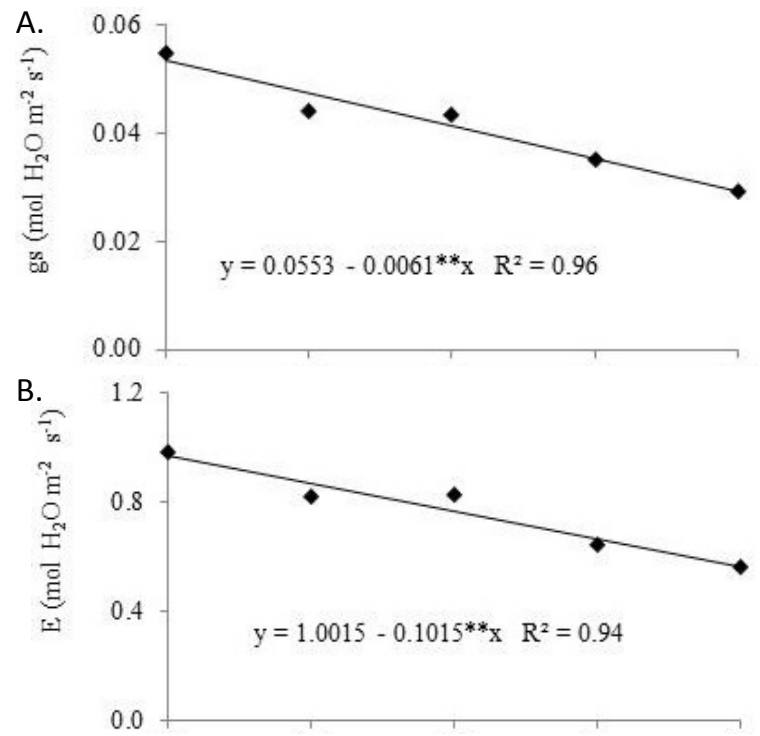

C.

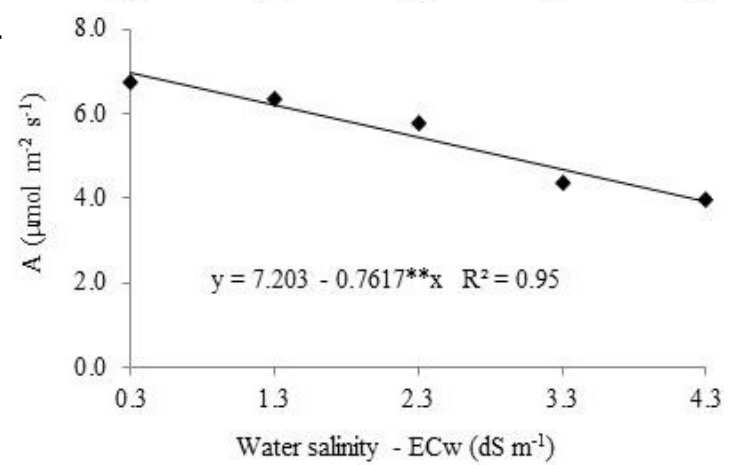

Figure 4. Mean values of stomatal conductance - gs (A), transpiration - $\mathrm{E}(\mathrm{B})$ and $\mathrm{CO}_{2}$ assimilation rate - $\mathrm{A}(\mathrm{C})$ in West Indian cherry plants as a function of irrigation water salinity - ECW at 170 days after transplanting - DAT. ** significant at $\mathrm{p} \leq 0.01$.

biochemical limitations (Roy et al., 2014; Gupta \& Huang, 2014; Silveira et al., 2016).
Regarding effects of fertilizer combinations, the stomatal conductance, transpiration and $\mathrm{CO}_{2}$ assimilation rate had higher values in plants fertilized with the combinations $\mathrm{C} 2$ and C3, followed by $\mathrm{C1}$ (Figure 5A; Figure 5B and Figure $5 \mathrm{C}$ ). On the other hand, $\mathrm{C} 4$ combination provided the lowest values for the analyzed variables, negatively affecting gas exchange, similar to what happened with the growth variables in the present study.

These results suggest that the $K$ supply up to a certain dose is the main responsible for attributing the highest values of stomatal conductance, given that $\mathrm{K}$ is the main nutrient that regulates, opens and closes stomata in plants (Taiz et al., 2017). The phenomenon occurs when this nutrient is accumulated in adequate concentrations in the guard cells, decreasing the osmotic potential and assisting in absorbing water from the adjacent cells. This promotes a turgor pressure increase and the stomata opening, consequently causing greater stomatal conductance. (Prajapati \& Modi, 2012).

The lower value of gs in fertilized plants with the greater C4 combination, may be related, mainly, to the high nitrogen dose, which in turn may have stimulated the malate extrusion from guard cells, causing the $\mathrm{K}^{+}$efflux and, as a consequence, the closing stomata (Shimazaki et al., 2007).

Knowing that the opening and closing of stomata regulate leaf gas exchange (Shimazaki et al., 2007), it is inferred that gs has affected the transpiration dynamics and the rate of $\mathrm{CO}_{2}$ assimilation, given that these variables response to different combinations of $\mathrm{N}$ and $\mathrm{K}_{2} \mathrm{O}$ fertilization were similar to gs (Figure 5A; Figure 5B and Figure 5C). Due to $\mathrm{C} 1, \mathrm{C2}$ and $\mathrm{C3}$ combinations having contributed to the greater opening of the stomata by the appropriate $\mathrm{K}$ concentrations, it is possible that there was a greater water loss through the stomata to the atmosphere in steam form, resulting in a higher transpiration rate (Figure 5B) (Taiz et al., 2017).

For instant carboxylation efficiency, the highest obtained value was in plants that received C3 combination fertilization, 

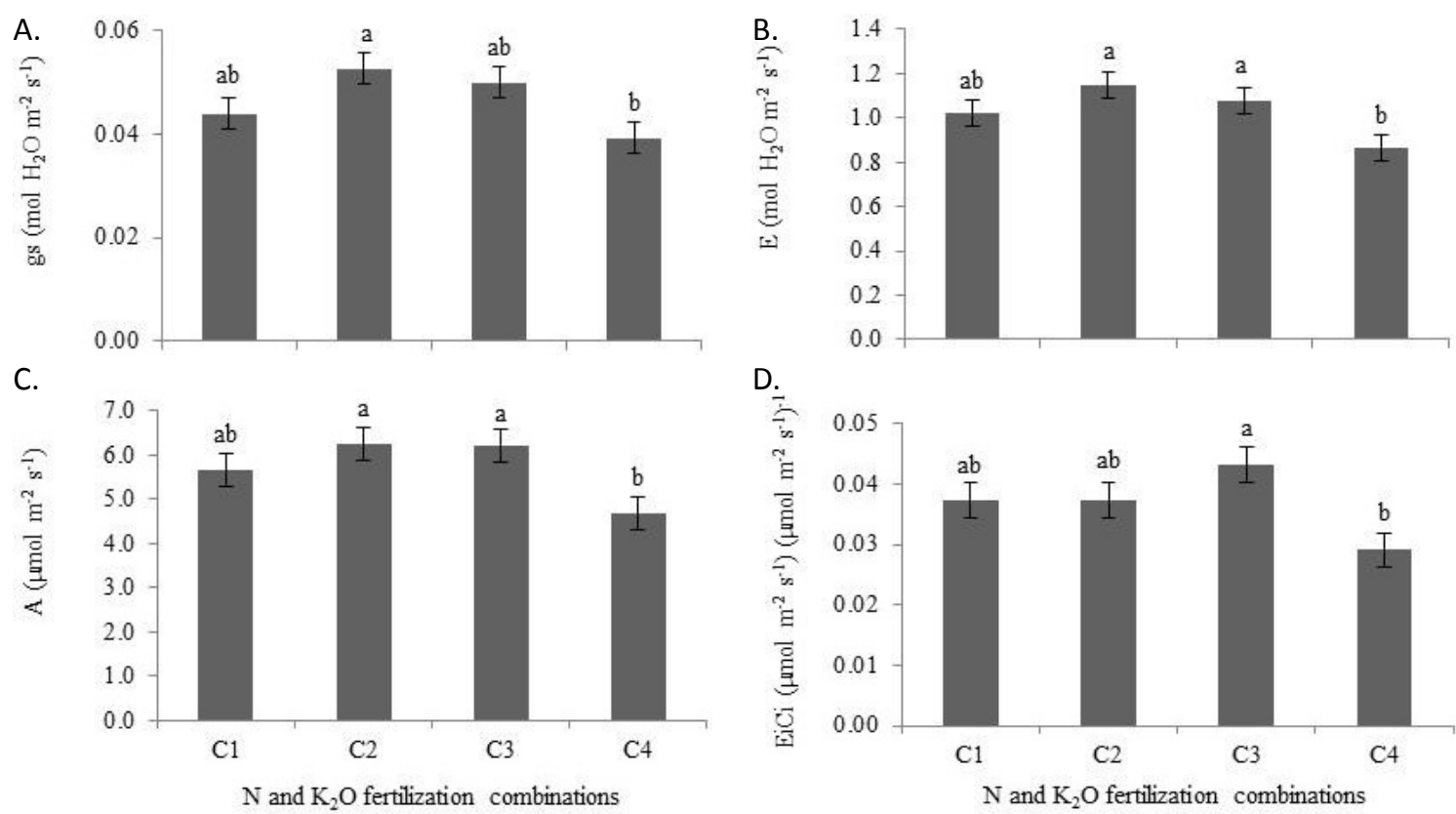

Figure 5 . Mean values of stomatal conductance $-\mathrm{gs}(\mathrm{A})$, transpiration $-\mathrm{E}(\mathrm{B}), \mathrm{CO}_{2}$ assimilation rate $-\mathrm{A}(\mathrm{C})$ and instant carboxylation efficiency - EiCi (D) in West Indian cherry plants fertilized with different nitrogen $(\mathrm{N})$ and potassium $\left(\mathrm{K}_{2} \mathrm{O}\right)$ dosage combinations, 230 days after transplant - DAT. Means followed by different letters indicate a significant difference between treatments by the Tukey test $(p<0.05)$. Bars represent the standard mean error $(n=3)$.

followed by $\mathrm{C} 2$ and $\mathrm{C} 1$ that did not differ statistically, with the lowest variable value obtained in the $\mathrm{C} 4$ combination (Figure $5 \mathrm{D})$, which differed only from the C3 combination. This variable represents the amount of carbon that the plant fixes in order to perform photosynthesis, per unit of carbon that is not fixed and accumulated inside leaves (Taiz et al., 2017). Therefore, the greatest efficiency of carbon fixation occurred until the $\mathrm{C} 3$ combination, favoring a higher rate of $\mathrm{CO}_{2}$ assimilation (Figure $5 \mathrm{C}$ ).

The lower value of instantaneous carboxylation efficiency found in plants fertilized with the highest $\mathrm{N}$ and $\mathrm{K}_{2} \mathrm{O}$ dose combination (C4) (Figure 5D) may be associated with an increase in the oxygenation activity of Rubisco enzyme in detriment of carboxylase, which occurs due to excessive $\mathrm{N}$ amount from fertilization, causing a lower carbon assimilation rate (Melo et al., 2009) (Figure 5C). Thus, in addition to the nutritional imbalance, negative effects on the activity of the carbon-fixing enzyme in photosynthesis can be considered yet another cause that affected the plants growth, when fertilized with the highest combination of $\mathrm{N}$ and $\mathrm{K}_{2} \mathrm{O}$ doses (C4).

\section{Conclusions}

Irrigating West Indian cherry with water salinity of up to $4.3 \mathrm{dS} \mathrm{m}^{-1}$ did not compromise the plant growth until 170 days after transplanting. A negative effect was manifested at 230 days after transplantation, from the stem diameter below the grafting, at its point, and above it, and primary shoots of the plants over the ECW of $2.32 \mathrm{dS} \mathrm{m}^{-1}$.

The combination of $\mathrm{C} 1$ fertilization $(70 \% \mathrm{~N}+50 \%$ of recommended $\mathrm{K}_{2} \mathrm{O}$ ) favored the gas exchange activity and promoted greater plant growth after 170 days after transplanting, regardless of the water salinity.
Tested combinations of nitrogen and potassium fertilization did not mitigate the effects of salt stress on the growth variables affected by the irrigation water salinity at 230 days after transplanting.

\section{Acknowledgements}

To the National Council for Scientific and Technological Development - CNPq for funding the research, to the Federal University of Campina Grande - UFCG/CCTA for use of infrastructure facilities and to the Coordination for the Improvement of Higher Education Personnel (CAPES) for the research grant.

\section{Literature Cited}

Alvarenga, C. F. S.; Silva, E.M.; Nobre, R. G.; Gheyi, H. R.; Lima, G.S.; Silva, L. A. Morfofisiologia de aceroleira irrigada com águas salinas sob combinações de doses de nitrogênio e potássio. Revista de Ciências Agrárias, v.42, n.1, p.194-205, 2019. https://doi.org/10.19084/RCA18215.

Arghavani, M.; Zaeimzadeh, A.; Savadkoohi, S.; Samiei, L. Salinity tolerance of Kentucky bluegrass as affected by nitrogen fertilization. Journal of Agricultural Science and Technology, v. 19, n. 1, p.173-183, 2017. http://journals.modares.ac.ir/article-23-2115-en.html. 02 Jul. 2019.

Ayers, R.S.; Westcot, D.W. Qualidade da água na agricultura. Campina Grande: Universidade Federal da Paraíba, 1999. 153p.

Byrt, C.S.; Munns, R.; Burtonc, R.A.; Gillihama, M.; Wegea, S. Root cell wall solutions for crop plants in saline soils. Plant Science, v. 269, p. 47-55, 2018. https://doi.org/10.1016/j.plantsci.2017.12.012.

Calgaro, M.; Braga, M.B. A cultura da acerola. 3.ed. Brasília: Embrapa, 2012. 144 p. (Coleção Plantar, 69). https://www. infoteca.cnptia.embrapa.br/infoteca/bitstream/doc/952709/1/ PLANTARAcerolaed032012.pdf. 28 Jul. 2018. 
Cavalcanti, F.J. Recomendações de adubação para o estado de Pernambuco: 2. aproximação. 3.ed. Recife: IPA, 2008. 212 p.

Ferreira, D.F. Sisvar: um sistema computacional de análise estatística. Ciência e Agrotecnologia, v. 35, n. 6, p. 1039-1042, 2011. https:// doi.org/10.1590/S1413-70542011000600001.

Gupta, B.; Huang, B. Mechanism of salinity tolerance in plants: Physiological, biochemical, and molecular characterization. International Journal of Genomics, v. 2014, Article 701596, 2014. https://doi.org/10.1155/2014/701596.

Instituto Nacional de Meteorologia - INMET. Estações e dados. http://www.inmet.gov.br/portal/index.php?r=estacoes/ estacoesAutomaticas. 03 Mar. 2018.

Li, H.; Yan, S; Zhao, L.; Tan, J.; Zhang, Q.; Gao, F.; Wang, P.; Hou, H.; $\mathrm{Li}, \mathrm{L}$. Histone acetylation associated up-regulation of the cell wall related genes is involved in salt stress induced maize root swelling. BMC Plant Biology, v. 14, Article 105, 2014. https://doi. org/10.1186/1471-2229-14-105.

Machado, R.M.A.; Serralheiro, R.P. Soil salinity: Effect on vegetable crop growth. Management practices to prevent and mitigate soil salinization. Horticulturae, v.3, n.2, Article 30, 2017. https://doi. org/10.3390/horticulturae3020030.

Medeiros, J.F. Qualidade da água de irrigação e evolução da salinidade nas propriedades assistidas pelo "GAT" nos estados do RN, PB e CE. Campina Grande: Universidade Federal da Paraíba, 1992. 173p. Dissertação Mestrado. http://dspace.sti.ufcg.edu.br:8080/ jspui/handle/riufcg/2896. 12 Out. 2018.

Melo, A.S.; Silva Júnior, C.D.; Fernandes, P.D.; Sobral, L.F.; Brito, M.E.B.; Dantas, J.D.M. Alterações das características fisiológicas da bananeira sob condições de fertirrigação. Ciência Rural, v. 39, n. 3, p.733-741, 2009. https://doi.org/10.1590/S010384782008005000101.

Morais, E.R.C.; Maia, C.E.; Oliveira, M. Qualidade da água para irrigação em amostras analíticas do banco de dados do Departamento de Solos e Geologia da Escola Superior de Agricultura de Mossoró, Mossoró-RN. Caatinga, v. 11, n. 1/2, p. 75-83, 1998. https://periodicos.ufersa.edu.br/index.php/ caatinga/article/view/2510/4968. 10 Out. 2018.

Prajapati, K.; Modi, H.A. The importance of potassium in plant growth - a review. Indian Journal of Plant Sciences, v. 1, n.2/3, p.177-186, 2012. http://www.cibtech.org/J-Plant-Sciences/ PUBLICATIONS/2012/Vol-1-No-2\&3/19-027...Prajapati...The... Importance...Growth.pdf. 05 Out. 2018.

Roy, S.; Negrão, S.; Tester, M. Salt resistant crop plants. Current Opinion in Biotechnology, v.26, p.115-124. 2014. https://doi. org/10.1016/j.copbio.2013.12.004.
Sá, F. V. S.; Gheyi, H. R.; Lima, G. S.; Paiva, E. P.; Silva, L. A.; Moreira, R. C. L.; Fernandes, P. D.; Dias, A. S. Ecophysiology of West Indian cherry irrigated with saline water under phosphorus and nitrogen doses. Bioscience Journal, v. 35, n. 1, p. 211-221, 2019. https:// doi.org/10.14393/BJ-v35n1a2019-41742.

Shimazaki, K.I; Doi, M.; Assmann, S.M.; Kinoshita, T. Light regulation of stomatal movement. Annual Review of Plant Biology, v.58, p.219-247, 2007. https://doi.org/10.1146/annurev. arplant.57.032905.105434.

Silva, E. M.; Gheyi, H. R.; Nobre, R. G.; Barbosa, J. L.; Souza, C. M. A. Morphology and production of West Indian cherry irrigated with saline waters under combinations of nitrogen-potassium fertilization. Revista Caatinga, v. 32, n. 4, p. 1027-1037, 2019. https://doi.org/10.1590/1983-21252019v32n419rc.

Silva, E.M.; Lima, G.S.; Gheyi, H.R.; Nobre, R.G.; SÁ, F.V.S.; Souza, L.P. Growth and gas exchanges in soursop under irrigation with saline water and nitrogen sources. Revista Brasileira de Engenharia Agrícola e Ambiental, v. 22, n. 11, p. 776-781, 2018. https://doi. org/10.1590/1807-1929/agriambi.v22n11p776-781.

Silva, M. L. S.; Trevizam, A. R. Interações iônicas e seus efeitos na nutrição das plantas. In: Mellis, E. E.; Quaggio, J. A (Orgs.). Uso de micronutrientes em cana-de-açúcar. Piracicaba: International Plant Nutrition Institute, 2015. p.10-16. (Informações agronômicas, 149). http://www.ipni.net/publication/IA-BRASIL. NSF/0/8C2796BCB76E0F9B83257E20006560E2/\$FILE/Page1016-149.pdf. 10 Out. 2018.

Silveira, J. A. G; Silva, S. L. F.; Silva, E. N.; Viégas, R. A. Mecanismos biomoleculares envolvidos com a resistência ao estresse salino em plantas. In: Gheyi, H. R.; Dias, N. S.; Lacerda, C. F; Gomes Filho, E (Orgs.). Manejo da salinidade na agricultura: Estudos básicos e aplicados. 2.ed. Fortaleza: INCTSal, 2016. p.181-197.

Souza, F.F.; Deon, M.D.; Cunha, J. M.; Calgaro, C.M. Contribuições das pesquisas realizadas na Embrapa Semiárido para a cultura da aceroleira. Petrolina: Embrapa Semiárido, 2017. 26 p. (Embrapa Semiárido. Documentos, 282). https://ainfo.cnptia.embrapa.br/ digital/bitstream/item/173370/1/SDC282.pdf. 12 Out. 2018.

Taiz, L.;Zeiger, E.; Møller, I. M.; Murphy, A. Fisiologia e desenvolvimento vegetal. 6.ed. Porto Alegre: Artmed, 2017. 858p.

Wang, M.; Zheng, Q.; Shen, Q.; Guo, S. The critical role of potassium in plant stress response. International Journal Molecular Sciences, v. 14 n. 4, p. 7370-7390, 2013. https://doi.org/10.3390/ijms14047370.

Zaki, S.S. Effect of compost and nitrogen fertilization on yield and nutrients uptake of rice crop under saline soil. Modern Chemistry and Applications, v.4, n.2, Article 183, 2016. https:// doi.org/10.4172/2329-6798.1000183. 